\title{
OPTIMASI PRODUKSI ENZIMATIS DIASILGLISEROL MELALUI GLISEROLISIS KONTINU
}

\author{
[Optimization of Enzymatic Diacylglycerol Production through Continuous Glycerolysis]
}

\author{
Tri-Panji1)*, Septiany C. Palilingan²) dan I Made Artika²) \\ 1) Balai Penelitian Bioteknologi Perkebunan Indonesia, Jl. Taman Kencana No. 1 Bogor \\ 2) Departemen Biokimia, Fakultas Matematika dan IImu Pengetahuan Alam, Institut Pertanian Bogor, Bogor
}

Diterima 24 Juni 2013 / Disetujui 10 Februari 2014

\begin{abstract}
Diacylglycerol (DAG) produced from crude palm oil (CPO) is one of the healthy oils that can be consumed for daily human diet. DAG production in Indonesia is constrained by the high cost of the mostly imported lipase. To overcome this problem, research of DAG production has been carried out using crude extracts of lipase produced by local species of fungi Rhizopus oryzae. This study aims to develop a continuous process of enzymatic glycerolysis of CPO for DAG production; to establish optimum conditions of DAG production which includes flow rate of CPO and glycerolysis time; and to test the performance of lipase from the local mold R. oryzae in catalyzing continuous process of glycerolysis for the production of DAG. Lipase isolation was carried out by acetone precipitation and lipase was used as a catalyst in the continuous glycerolysis process. The glycerolysis was conducted by reacting CPO with glycerol continuously at various time periods. The optimum condition of automatic continuous glycerolysis process was achieved at a CPO flow rate of $3 \mathrm{~mL} / \mathrm{min}$ with a glycerolysis time at the 18 cycles (9 hours). The conversion of DAG was $29 \%$. The performance of lipase was proven to remain stable up to 3 times changes of CPO substrate for 9 hours of glycerolysis process with the best condition at the 3 cycles and can improved conversion of DAG until $37 \%$.
\end{abstract}

Keywords: continuous glycerolysis, crude palm oil, diacylglycerol, lipase, Rhizopus oryzae

\begin{abstract}
ABSTRAK
Diasilgliserol (DAG) merupakan salah satu jenis minyak sehat (healthy oil) yang dapat dijadikan menu diet sehari-hari oleh masyarakat. DAG dapat diproduksi dari crude palm oil (CPO) yang ketersediaannya melimpah di Indonesia. Akan tetapi produksi DAG di Indonesia terkendala oleh mahalnya harga lipase yang masih diimpor dari luar negeri. Untuk mengatasi masalah tersebut, telah dilakukan penelitian produksi DAG menggunakan ekstrak kasar lipase yang dihasilkan dari jenis kapang lokal Rhizopus oryzae. Penelitian ini bertujuan untuk melakukan otomatisasi proses gliserolisis dalam produksi enzimatis DAG yang dilakukan secara kontinu; menetapkan kondisi optimum produksi DAG yang meliputi laju alir CPO dan waktu gliserolisis serta menguji kinerja lipase dari kapang lokal $R$. oryzae dalam mengkatalisis proses gliserolisis kontinu untuk produksi DAG. Isolasi lipase dilakukan melalui pengendapan dengan aseton dan lipase tersebut digunakan sebagai katalis dalam proses gliserolisis kontinu. Gliserolisis kontinu dilakukan dengan mereaksikan CPO yang dialirkan secara kontinu dengan gliserol pada berbagai variasi waktu. Hasil penelitian menunjukkan bahwa sistem yang dirancang dalam penelitian ini dapat bekerja secara otomatis untuk proses gliserolisis kontinu. Kondisi optimum dicapai pada laju alir CPO $3 \mathrm{~mL} /$ menit dengan waktu gliserolisis pada siklus ke-18 (jam ke-9), dengan konversi produk DAG yang dihasilkan sebesar 29\%. Adanya perlakuan 3 kali penggantian substrat CPO menunjukkan kinerja lipase terbukti tetap stabil selama 9 jam proses gliserolisis dengan kondisi terbaik pada siklus ke-3 dan meningkatkan konversi produk DAG hingga mencapai $37 \%$.
\end{abstract}

Kata kunci: diasilgliserol, enzim lipase, gliserolisis kontinu, minyak sawit mentah, Rhizopus oryzae

\section{PENDAHULUAN}

Kelapa sawit merupakan komoditas perkebunan yang berpotensi besar untuk terus dikembangkan dalam bidang agroindustri. CPO merupakan produk turunan pertama dari buah kelapa sawit. Beberapa produk turunan bermanfaat dari bahan baku CPO, seperti minyak sehat (healthy oil), specialty fat dan confectionery fat, memiliki harga yang lebih tinggi dar minyak makan (cooking oil) yang dikonsumsi oleh masyarakat. Salah satu jenis minyak sehat yang dapat diproduksi dari CPO adalah minyak Diasilgliserol (DAG). Terjadinya peningkatan kasus obesitas akibat tingginya konsumsi minyak makan di berbagai negara dan memicu berbagai penyakit degeneratif,

*Penulis Korespondensi:

Email: tri_panji@yahoo.com; Telp. 0251-8324048,Fax. 0251-8328516 telah mendorong masyarakat untuk mengonsumsi minyak sehat seperti DAG (Suharyanto et al. 2011).

DAG dapat berperan sebagai healthy oil karena DAG dapat dimetabolisme secara efisien sebagai sumber energi, sehingga dapat mencegah akumulasi lemak dalam tubuh (Matsuo, 2004; Takase, 2007; Morita dan Soni, 2009; Yuan et al. 2010). Manfaat lain DAG adalah sebagai emulsifier dan surfaktan makanan (Anggirasti et al. 2008) serta bahan anti mikroba (Nuraida et al. 2008).

Secara komersial DAG diproduksi melalui proses gliserolisis secara batch pada suhu tinggi dengan mereaksikan triasilgliserol (TAG) dengan gliserol atau esterifikasi antara asam lemak dan gliserol dibantu katalis anorganik (basa). Kelemahan dalam penggunaan suhu tinggi, antara lain membutuhkan energi besar, terbentuk produk samping toksik, serta 
menimbulkan warna dan rasa yang tidak diinginkan pada produk. Proses gliserolisis secara enzimatis (enzim lipase) telah banyak dilakukan sebagai metode alternatif dalam produksi DAG, karena memiliki keuntungan antara lain spesifitas tinggi, penggunaan energi rendah, ramah lingkungan, produk yang dihasilkan lebih aman serta warna produk lebih terang (Suharyanto et al. 2011; Noureddini et al. 2004).

Enzim lipase yang dihasilkan dari sejumlah kapang seperti Penicillium sp, Rhizopus sp dan Aspergillus niger diketahui aktif menghasilkan lipase dalam substrat CPO. Akan tetapi harga lipase komersial yang relatif mahal sehingga harus diimpor dari luar negeri (Suharyanto et al. 2011).

Masalah tingginya harga lipase, mendorong para peneliti untuk memproduksi dengan harga yang lebih murah. Salah satunya dengan memfermentasikan jenis kapang lokal seperti Neurospora sitophila dan Rhizopus oryzae yang diketahui mampu menghasilkan lipase (Tri-Panji et al. 2008). Melihat berbagai manfaat DAG bagi kesehatan serta potensi lipase yang dihasilkan dari kapang lokal sebagai biokatalis produksi DAG, maka perlu dilakukan penelitian lebih lanjut tentang metode produksi DAG. Suharyanto et al. 2011 sebelumnya telah melakukan optimasi produksi DAG melalui gliserolisis enzimatis dengan sistem batch, dan kondisi optimumnya dicapai pada suhu kamar, $\mathrm{pH}$ netral, konsentrasi substrat $3 \mathrm{~g} \mathrm{( \pm}$ $4 \%$ dari total medium gliserolisis) selama 18 jam. Penerapan teknik gliserolisis enzimatis untuk produksi DAG dalam penelitian ini, dilakukan dengan sistem kontinu dengan menambahkan informasi yang telah diperoleh dari penelitian Suharyanto et al. 2011. Tujuan dari penelitian ini adalah untuk melakukan otomatisasi proses gliserolisis dalam produksi enzimatis DAG yang dilakukan dengan sistem kontinu; menetapkan kondisi optimum produksi DAG yang belum dilakukan pada penelitian sebelumnya yang dibatasi pada variasi laju alir substrat (CPO), waktu gliserolisis serta menguji kinerja lipase dari kapang lokal $R$. oryzae dalam mengkatalisis proses gliserolisis kontinu untuk produksi DAG dengan perlakuan penggantian substrat baru sebanyak 3 kali.

\section{BAHAN DAN METODE}

\section{Bahan}

CPO yang digunakan untuk produksi DAG berasal dari Pabrik Kelapa Sawit (PKS) Kebun Bekri, PTPN VII, Lampung. Rhizopus oryzae untuk produksi lipase adalah isolat lokal koleksi Balai Penelitian Bioteknologi Perkebunan Indonesia (BPBPI) yang dipelihara pada media Potato Dextrose Agar (PDA) (Difco) dan diremajakan setiap dua minggu.

\section{Kondisi kultur dan penyiapan lipase dari $R$. oryzae}

Kultur kapang $R$. oryzae dalam media PDA (Difco) pada cawan petri yang berumur 3-4 hari, sporanya diambil sebanyak 1 ose dan diinokulasikan dalam media fermentasi yang terdiri dari campuran 0.25 gram $\mathrm{MgSO}_{4}$ (E-Merck), 0.25 gram $\mathrm{KH}_{2} \mathrm{PO}_{4}$ (E-Merck), 12.5 gram pepton (Difco) yang dilarutkan dalam 250 $\mathrm{mL}$ akuades yang mengandung CPO 3\%. Kemudian diinkubasi pada suhu ruang $\left(25-30^{\circ} \mathrm{C}\right)$ selama lima hari sambil di shaker (IKA Labortechnik HS 250 Basic) dengan kecepatan 75 rpm. Setelah lima hari spora yang tumbuh dipisahkan dengan penyaringan vakum menggunakan kertas saring (Whatman No. 40) dan filtrat yang diperoleh diekstraksi dengan menggunakan aseton (E-Merck) dingin dengan perbandingan filtrat dan aseton $1: 2$ (v : v), dan di sentrifugasi (Beckman Allegra 64 R) dengan kecepatan $10.000 \mathrm{rpm}$ selama 15 menit pada suhu $4^{\circ} \mathrm{C}$. Endapan yang diperoleh dilarutkan dalam larutan buffer Tris$\mathrm{HCl}$ (E-Merck) $0.05 \mathrm{M} \mathrm{pH} \mathrm{7.} \mathrm{Ekstrak} \mathrm{lipase} \mathrm{yang} \mathrm{diperoleh}$ kemudian disimpan dalam freezer sampai siap digunakan untuk bahan percobaan selanjutnya.

\section{Optimasi produksi DAG dengan sistem kontinu}

Proses optimasi produksi DAG dilakukan melalui proses gliserolisis kontinu dalam suatu reaktor dengan cara mengalirkan substrat CPO secara kontinu menggunakan selang dengan bantuan pompa peristaltik (peristaltic pump 131900) (Gambar 1).
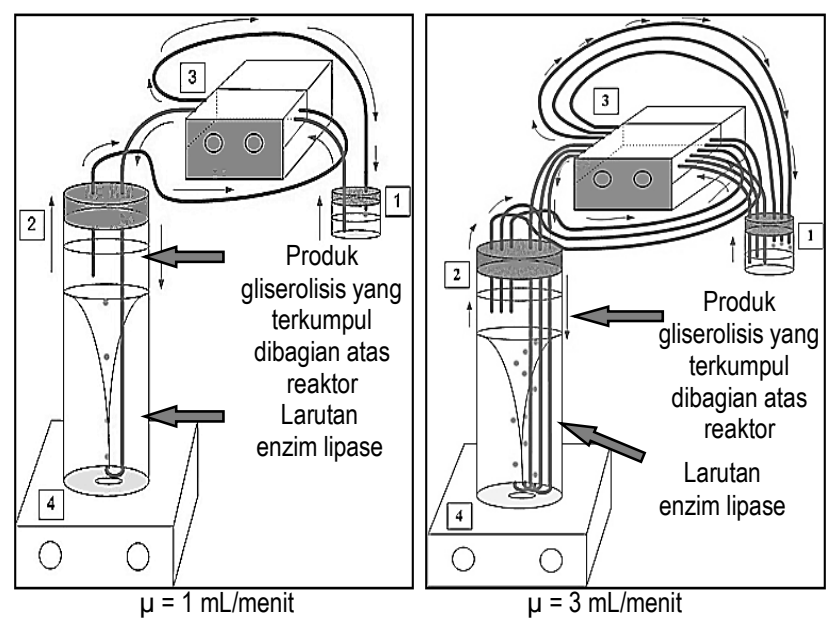

Keterangan : (1) Sampel CPO (Sampling point); (2) Bioreaktor gliserolisis; (3) Pompa peristaltik; (4) Pengaduk (Magnetic stirrer)

Gambar 1. Skema proses gliserolisis kontinu

Substrat CPO dialirkan dari bagian bawah reaktor tabung kaca berkapasitas $\pm 2.500 \mathrm{~mL}$ hingga naik ke atas (upward flow). Ketika substrat kontak dengan enzim dan terbentuk produk yang tertampung di bagian atas reaktor, produk tersebut dialirkan kembali ke dalam sampling point. Waktu yang diperlukan ketika substrat dialirkan ke dalam reaktor hingga terbentuk produk dibagian atas reaktor dan dialirkan kembali ke sampling point disebut sebagai "satu siklus" yang setara dengan \pm 30 menit. Proses "siklus" tersebut dilakukan secara terus-menerus hingga mencapai 48 siklus yang setara dengan 24 jam gliserolisis. Komponen yang dimasukkan dalam reaktor adalah $1 \mathrm{~mL}$ ekstrak lipase, 24 gram gliserol (E-Merck), $1.500 \mathrm{~mL}$ buffer Tris- $\mathrm{HCl}$ (E-Merck) 0.05 M pH 7, $600 \mathrm{~mL}$ n-heksana (E-Merck) serta $90 \mathrm{~g}$ CPO. Komposisi komponen tersebut merupakan perbesaran perbandingan sebesar 30 kali (skala lab) dari komposisi komponen medium gliserolisis yang telah dilakukan oleh Suharyanto et al. (2011) melalui sistem batch. Untuk menjaga agar campuran komponen dalam reaktor tetap homogen, maka dilakukan pengadukan menggunakan magnetic stirrer. Pengambilan sampel minyak (produk) hasil gliserolisis kontinu sebanyak $(3 \mu \mathrm{L})$ dilakukan berdasarkan variasi waktu per "siklus", yaitu siklus ke-0, 9, 18, 27, 36 dan 45. Analisis 
komponen produk hasil gliserolisis kontinu dilakukan menggunakan Kromatografi Lapis Tipis (KLT). Proses gliserolisis kontinu tersebut terlebih dahulu telah dilakukan berdasarkan variasi laju alir CPO $(\mu)$ yaitu 1 dan $3 \mathrm{~mL} /$ menit dengan waktu gliserolisis selama 4 jam (siklus ke-8), 18 jam (siklus ke-36), 21 jam (siklus ke-42) dan 24 jam (siklus ke-48).

\section{Penentuan kinerja lipase dalam mengkatalisis proses gliserolisis kontinu}

Untuk mengetahui kinerja lipase dalam mengkatalisis proses gliserolisis kontinu, dilakukan perlakuan penggantian substrat CPO sebanyak 3 kali setiap dilakukan proses gliserolisis kontinu selama 3 jam, sehingga proses keseluruhan dilakukan selama $3 \times 3$ jam yaitu 9 jam untuk total proses gliserolisis kontinu, dimana komponen lain dalam bioreaktor gliserolisis tetap dipertahankan. Selanjutnya setiap 30 menit (1 siklus) selama 3 kali penggantian substrat CPO dilakukan pengambilan sampel $(3 \mu \mathrm{L})$ untuk dianalisis komponen produk nya menggunakan KLT. Metode gliserolisis kontinu untuk penentuan kinerja lipase mengacu pada prosedur yang telah dilakukan pada tahap optimasi produksi DAG.

\section{Analisis produk hasil gliserolisis kontinu dengan KLT}

Fraksi massa komponen TAG, DAG, monoasilgliserol (MAG) dan asam lemak bebas (ALB) dari reaksi gliserolisis kontinu dianalisis dengan metode KLT. Lempeng yang digunakan adalah lempeng silika gel G-60. Sebanyak $3 \mu \mathrm{L}$ sampel minyak ditotolkan sedikit demi sedikit ke dalam lempeng tersebut dan dielusikan dengan campuran petroleum benzena (E-Merck): dietileter (E-Merck): asam asetat glasial (E-Merck) dengan perbandingan $90: 10: 1(\mathrm{v}: \mathrm{v}: \mathrm{v})$. Lempeng KLT yang sudah dielusikan dibiarkan mengering terlebih dahulu, kemudian visualisasi nodanya dilakukan dengan menggunakan uap iodine. Kristal iodine (E-Merck) dituangkan ke dalam cawan petri hingga rata. Lempeng KLT yang sudah kering diletakkan di atas cawan petri selama dua menit (hingga terlihat noda cokelat). Noda yang terlihat langsung diberi tanda menggunakan pensil. Noda yang terlihat dijiplak menggunakan kertas HVS $80 \mathrm{~g}$ lalu ditimbang bobotnya. Fraksi massa komponen dihitung berdasarkan persentase perbandingan berat komponen terhadap berat total.

\section{Penentuan nilai dan laju konversi produk hasil gliserolisis kontinu}

Setelah komponen TAG, DAG, MAG dan ALB dianalisis dengan metode $\mathrm{KLT}$, dapat ditentukan nilai konversi serta laju konversi masing-masing komponen tersebut berdasarkan persentase peningkatan fraksi massa komponen terhadap fraksi massa awal serta persen peningkatan fraksi massa komponen terhadap fraksi massa awal per satuan waktu gliserolisis.

\section{HASIL DAN PEMBAHASAN}

\section{Proses gliserolisis kontinu secara otomatis}

Proses gliserolisis kontinu yang dilakukan secara otomatis untuk memproduksi DAG telah berhasil dilakukan dalam skala laboratorium. Rancangan sistem pemroses berjalan dengan baik, dan sistemnya dapat berjalan secara otomatis. Proses otomatisasi tersebut menunjukkan bahwa proses gliserolisis secara kontinu untuk produksi DAG dapat berlangsung dengan lebih cepat, mudah dan efisien, dibandingkan dengan proses gliserolisis secara batch. Hal tersebut terbukti dari komposisi produk DAG yang terbentuk mencapai kondisi optimum dengan waktu yang lebih cepat. Selain itu sistem otomatisasi lebih mudah, karena melalui sistem ini hanya menggunakan satu bioreaktor sehingga tidak diperlukan lagi banyak wadah ataupun penggantian wadah untuk menampung produk seperti pada proses batch. Hal ini tentu saja memperkecil keterlibatan tenaga manusia, dan menjadi suatu metode alternatif yang dapat dikembangkan dalam skala industri (Suharyanto et al. 2006).

\section{Laju alir CPO optimum produksi DAG melalui gliserolisis kontinu}

Optimasi produksi DAG melalui proses gliserolisis kontinu dilakukan dengan variasi laju alir substrat (CPO) dan waktu gliserolisis. Data pada Gambar 2 menunjukkan perbandingan fraksi massa produk DAG yang terbentuk selama gliserolisis kontinu dengan perbedaan laju alir CPO.

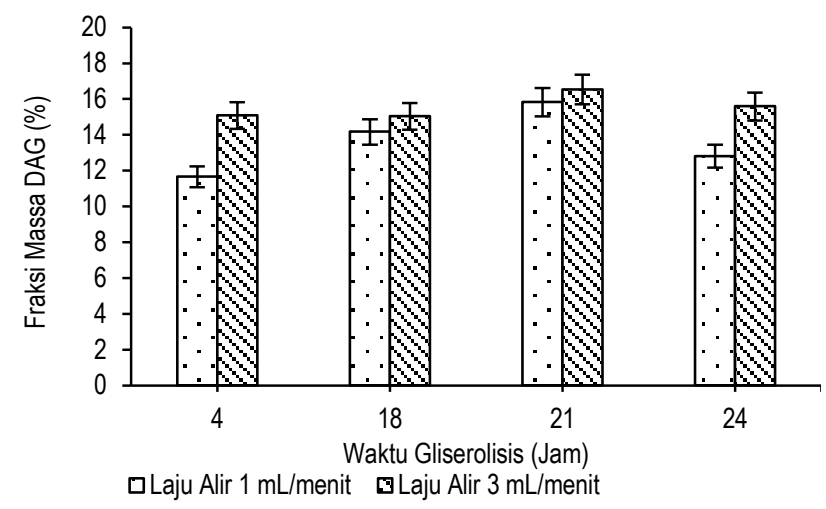

Gambar 2. Perbandingan fraksi massa DAG selama gliserolisis kontinu dengan laju alir CPO berbeda

Dari Gambar 2 dapat dilihat bahwa fraksi massa produk DAG pada laju alir $3 \mathrm{~mL} / \mathrm{menit}$ cenderung lebih tinggi dibandingkan dengan laju alir $1 \mathrm{~mL} /$ menit. Hal ini mengindikasikan adanya hubungan antara kecepatan alir substrat CPO dengan fraksi massa produk DAG. Adanya laju alir substrat yang lebih cepat menyebabkan proses kerja lipase dalam mengkatalisis pembentukan produk DAG baik melalui hidrolisis TAG maupun esterifikasi ALB dengan gliserol menjadi lebih cepat. Substrat yang dibutuhkan lipase untuk membentuk produk disuplai/diumpan dengan laju alir yang lebih cepat ke dalam bioreaktor gliserolisis dan memungkinkan terjadinya kontak enzim dengan substrat yang lebih banyak, sehingga laju alir substrat yang lebih cepat menghasilkan produk DAG yang lebih tinggi. Kittikun et al. 2008 telah melakukan produksi MAG dan DAG secara kontinu dalam packed-bed reactor (PBR) selama 96 jam dengan melakukan perbesaran laju alir substrat dari $0.02 \mathrm{~mL} /$ menit menjadi $0.2 \mathrm{~mL} /$ menit, dan didapatkan hasil bahwa laju alir yang lebih besar yaitu $0.2 \mathrm{~mL} / \mathrm{menit}$ menunjukkan peningkatan produktivitas dibandingkan laju alir 0.02 $\mathrm{mL} /$ menit. Hal tersebut menunjukkan bahwa laju alir dapat 
mempengaruhi terbentuknya produk DAG dalam proses gliserolisis kontinu.

\section{Waktu gliserolisis optimum produksi DAG secara kontinu}

Optimasi produksi DAG melalui gliserolisis kontinu yang kedua dilakukan dengan variasi waktu gliserolisis berdasarkan siklus perputaran substrat/produk. Satu siklus merupakan waktu yang dibutuhkan untuk mengalirkan total substrat CPO yang digunakan sampai terbentuk produk. Hal ini merupakan waktu total yang dibutuhkan ketika substrat CPO dialirkan ke dalam bioreaktor melalui selang yang kemudian mengalir naik ke atas (upward flow) sampai terbentuk produk pada bagian atas bioreaktor hingga dialirkan kembali ke sampling point. Data pada Gambar 3 menunjukkan fraksi massa produk DAG yang terbentuk dengan variasi waktu gliserolisis.

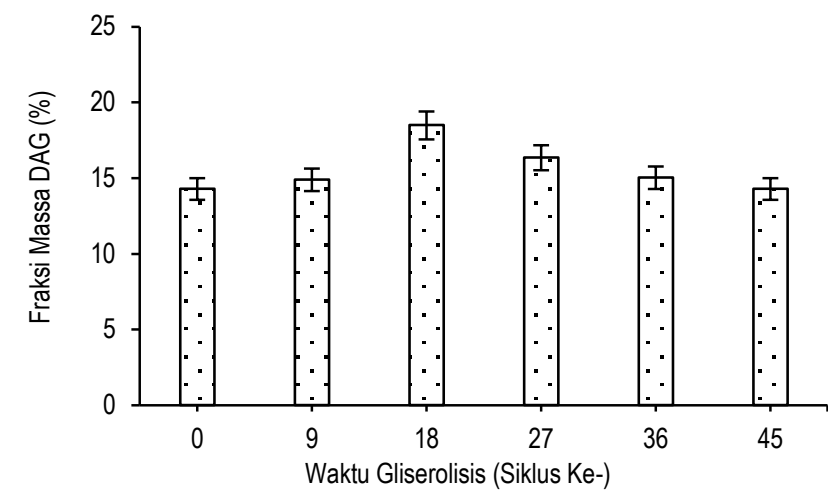

Gambar 3. Fraksi massa DAG dengan variasi waktu gliserolisis

Data pada Gambar 3 menunjukkan bahwa fraksi massa produk DAG meningkat hingga siklus ke-18, kemudian terus menurun pada siklus ke-27, 36 sampai 45 . Dari hasil ini dapat dilihat bahwa fraksi massa produk DAG mencapai nilai tertinggi pada waktu gliserolisis siklus ke-18, setiap siklus gliserolisis membutuhkan waktu 30 menit maka untuk siklus ke-18 setara dengan jam ke-9. Oleh karena itu, waktu gliserolisis optimum yang terpilih adalah pada siklus ke-18 (jam ke-9) dengan fraksi DAG sebesar $18.5 \%$. Hasil ini menunjukkan bahwa waktu gliserolisis untuk memproduksi DAG dua kali lipat lebih cepat dibandingkan dengan yang dilaporkan Suharyanto et al. (2011) menggunakan lipase dari $R$. oryzae yang sama yaitu 18 jam dan oleh Tri-Panji et al. (2008) menggunakan lipase asal Neurospora sitophila yaitu 10 hari, dimana keduanya menggunakan proses gliserolisis dengan sistem batch. Gliserolisis sistem batch yang lain juga telah dilakukan oleh Valerio et al. 2010 untuk produksi MAG dan DAG dengan sistem bebas pelarut menggunakan lipase komersial Novozym 435 dengan penambahan surfaktan Tween 65 pada substrat olive oil dan didapatkan fraksi DAG sebesar $17 \%$. Untuk gliserolisis sistem kontinu telah dilakukan antara lain oleh Kaewthong et al. 2005 dan Kittikun et al. 2008 dengan menggunakan continous stirredtank reactor (CSTR) dan packed-bed reactor (PBR), lipase komersial IM-PS (Pseudomonas sp), substrat palm olein selama 96 jam dan didapatkan rata-rata fraksi MAG dan DAG yang terbentuk sebesar 14 dan $2 \%$.

Pada Gambar 3 adanya peningkatan fraksi massa DAG hingga mencapai nilai optimum disebabkan oleh kerja lipase yang menghidrolisis TAG menjadi DAG, dapat juga diperoleh dari proses esterifikasi MAG dengan ALB ataupun ALB dengan gliserol, sedangkan penurunan fraksi massa DAG disebabkan karena DAG mengalami hidrolisis kembali oleh lipase menjadi MAG dan ALB. Hal ini karena kerja dari lipase yang dapat mengkatalisis proses dua arah, yaitu hidrolisis dan esterifikasi (Turner et al. 2004; Lumor dan Akoh, 2008). Aktivitas katalitik lipase akan lebih mengarah ke reaksi hidrolisis ketika aktivitas air dalam sistem reaksi lebih tinggi, sedangkan reaksi akan lebih mengarah ke proses esterifikasi ketika aktivitas air lebih rendah sehingga akan menghasilkan konversi pembentukan ikatan ester yang lebih tinggi dan dalam suasana pelarut yang lebih hidrofobik (Sasi et al. 2006). Perubahan fraksi massa produk lain selain DAG yang terbentuk selama gliserolisis kontinu ketika dibandingkan dengan fraksi massa awalnya dapat dilihat pada Gambar 4.

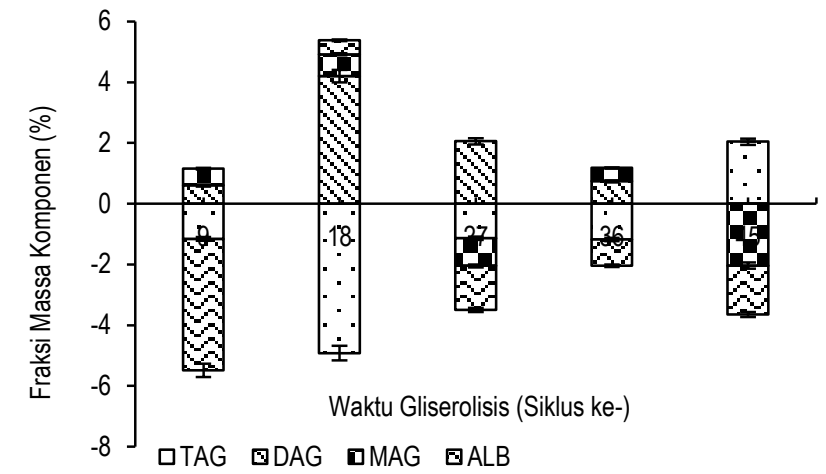

Gambar 4. Perubahan fraksi massa produk TAG, DAG, MAG dan ALB dibandingkan fraksi massa awal

Gambar 4 menunjukkan bahwa selama gliserolisis kontinu berlangsung, lipase dapat sekaligus mengkatalisis dua proses berbeda secara bersamaan yaitu hidrolisis dan esterifikasi. Adanya nilai positif menunjukkan bahwa komponen mengalami peningkatan fraksi massa sedangkan nilai negatif menunjukkan bahwa komponen mengalami pengurangan fraksi massa ketika dibandingkan dengan fraksi massa awal (sebelum gliserolisis). Peningkatan fraksi massa produk disebabkan karena reaktan mengalami hidrolisis atau esterifikasi, sedangkan pengurangan fraksi massa disebabkan karena reaktan terhidrolisis sehingga produk yang terbentuk berkurang fraksi massanya. Gambar 5 menunjukkan nilai konversi fraksi massa produk DAG dibandingkan fraksi massa DAG awal.

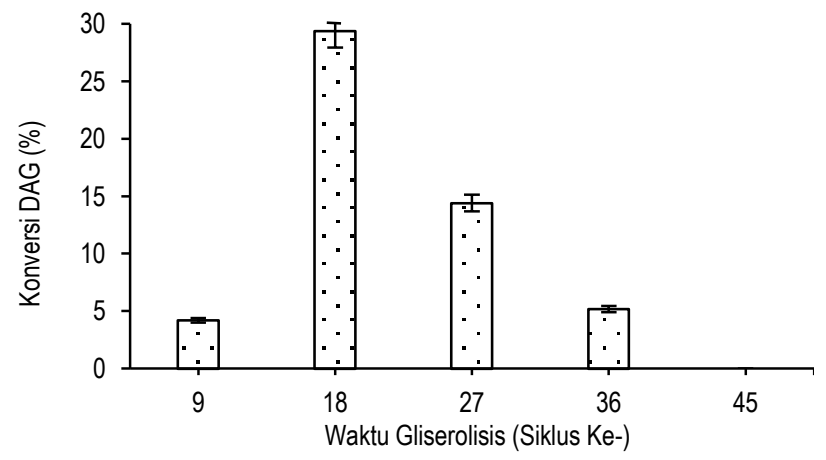

Gambar 5. Nilai konversi fraksi massa DAG dibandingkan dengan fraksi massa DAG awal 
Gambar 5 menunjukkan adanya pola yang hampir sama dengan Gambar 3, yaitu nilai konversi DAG tertinggi terdapat pada siklus ke-18 (jam ke-9). Artinya bahwa ada korelasi antara fraksi massa (Gambar 3) dan nilai konversi DAG. Nilai konversi DAG merupakan besarnya peningkatan persentase fraksi massa produk DAG ketika dibandingkan dengan fraksi massa DAG awal (sebelum gliserolisis). Nilai konversi DAG tertinggi terdapat pada siklus ke-18 (jam ke-9) sebesar $29 \%$.

Hal ini masih lebih rendah jika dibandingkan dengan gliserolisis kontinu yang dilakukan oleh Noureddini et al. (2004) dengan substrat minyak kedelai dengan nilai konversi DAG sebesar $36 \%$. Akan tetapi proses tersebut masih dilakukan secara kimiawi menggunakan katalis basa (natrium hidroksida) pada suhu tinggi $\left(230^{\circ} \mathrm{C}\right)$ dan berdampak pada kualitas produk, sehingga metode gliserolisis kontinu secara enzimatis dalam penelitian ini memiliki keunggulan yaitu dilakukan pada suhu rendah, tidak memerlukan energi yang besar serta dapat menghasilkan produk dengan nilai konversi yang tidak jauh berbeda (selisih 7\%). Akan tetapi nilai konversi DAG perlu ditingkatkan dengan menggunakan lipase dengan aktivitas dan stabilitas yang lebih baik, salah satunya dapat dilakukan dengan perlakuan pemurnian lipase, karena dalam penelitian ini lipase yang digunakan masih dalam bentuk ekstrak kasar dengan aktivitas sebesar $1.091 \mathrm{U}$. Selanjutnya, ketika didapatkan nilai konversi DAG, dapat pula ditentukan laju konversi produk DAG dibandingkan dengan kondisi awalnya per satuan waktu gliserolisis (Gambar 6).

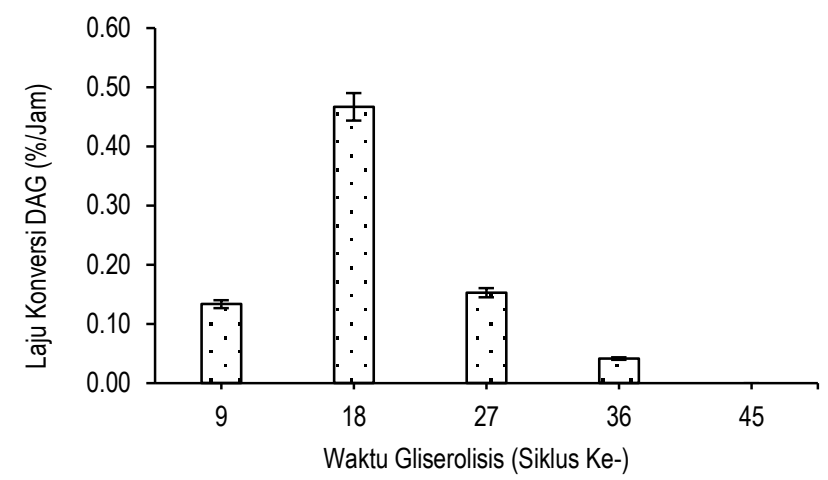

Gambar 6. Laju konversi produk DAG dibandingkan dengan kondis awalnya per satuan waktu gliserolisis

Gambar 6 menunjukkan nilai laju konversi produk DAG selama proses gliserolisis kontinu ketika dibandingkan dengan kondisi awalnya. Laju konversi merupakan kecepatan konversi fraksi massa produk DAG yang terbentuk dibandingkan dengan fraksi massa DAG awal per satuan waktu gliserolisis. Pada Gambar 6 dapat dilihat bahwa laju konversi DAG tertinggi terdapat pada siklus ke-18 (jam ke-9), sebesar $0.47 \%$ /jam. Artinya bahwa pada siklus ke-18 terdapat sebesar $0.47 \%$ peningkatan fraksi massa DAG per jam reaksi gliserolisis ketika dibandingkan dengan kondisi awalnya. Hal ini sejalan dengan data pada Gambar 3 dan Gambar 5 yang menunjukkan bahwa persen fraksi massa dan konversi DAG tertinggi juga terdapat pada siklus ke-18 (jam ke-9). Dengan demikian terlihat adanya korelasi yang berbanding lurus antara persen fraksi massa (Gambar 3), nilai konversi (Gambar 5) serta laju konversi DAG (Gambar 6). Pada siklus ke-45 terlihat bahwa laju konversi DAG adalah nol. Artinya bahwa pada siklus ke-45 secara perhitungan tidak terdapat peningkatan persentase fraksi massa DAG per satuan waktu gliserolisis dibandingkan kondisi awalnya, sehingga pada siklus ke-45 fraksi massa produk DAG konstan dan yang mengalami perubahan diduga adalah komponen produk yang lain yaitu TAG, MAG dan ALB.

\section{Kinerja lipase dalam mengkatalisis proses gliserolisis kontinu}

Penentuan kinerja lipase sebagai biokatalis dalam proses gliserolisis kontinu, dilakukan setelah proses optimasi laju alir CPO dan waktu gliserolisis. Data pada Gambar 7 menunjukkan perbandingan fraksi massa produk DAG ketika dilakukan perlakuan penggantian substrat CPO.

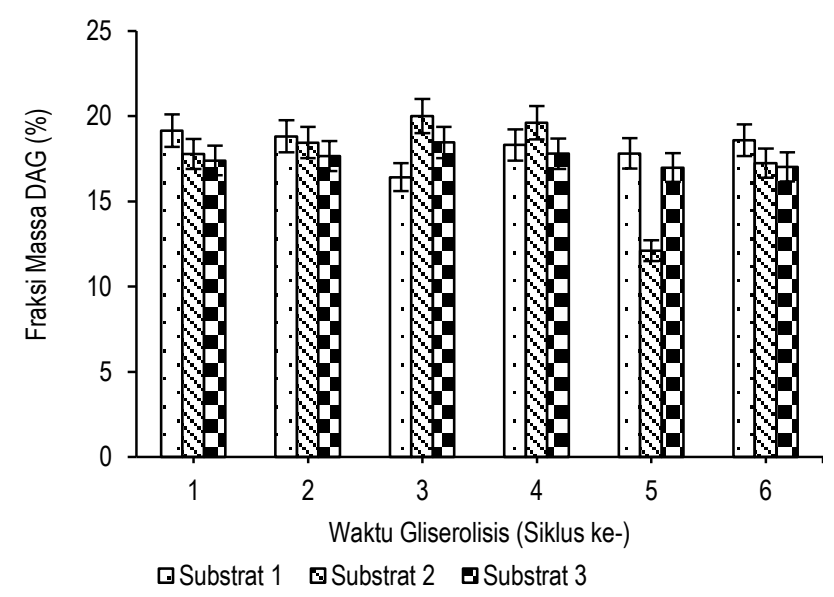

Gambar 7. Perbandingan fraksi massa produk DAG selama 9 jam gliserolisis dengan perlakuan penggantian substrat CPO sebanyak 3 kali per 3 jam gliserolisis

Data pada Gambar 7 menunjukkan bahwa lipase mampu untuk mempertahankan kinerjanya dalam mengkatalisis proses gliserolisis kontinu. Hal ini terlihat dari fraksi massa produk DAG yang terbentuk pada tiap siklus dan tiap perlakuan penggantian substrat CPO yang relatif sama. Hal ini membuktikan bahwa aktivitas lipase tetap stabil dan tidak menurun drastis seiring dengan bertambahnya perlakuan penggantian substrat dan waktu gliserolisis. Ketika dihubungkan dengan fraksi massa DAG pada kondisi awal, maka dapat ditentukan nilai konversi produk DAG dibandingkan dengan komposisi DAG awal (sebelum gliserolisis) (Gambar 8).

Data pada Gambar 8 menunjukkan bahwa nilai persen konversi DAG tertinggi yang mampu dihasilkan sebesar 37\% pada siklus ke-3 dan penggantian substrat ke-2, dengan total waktu gliserolisis adalah $4.5 \mathrm{jam}$. Waktu gliserolisis tersebut dua kali lebih cepat dibandingkan waktu gliserolisis optimum yang diperoleh saat proses optimasi produksi DAG (Gambar 3) yaitu 9 jam, dengan nilai konversi DAG sebesar 29\% (Gambar 5). Hal ini diduga karena saat dilakukan optimasi waktu gliserolisis tidak dilakukan proses penggantian substrat, artinya substrat yang digunakan tetap sama hingga akhir proses, sedangkan untuk prosedur penentuan kinerja lipase dilakukan perlakuan sampai 3 kali penggantian substrat. Hal ini yang menjadi penyebab konversi DAG pada prosedur penentuan kinerja lipase lebih besar daripada proses optimasi waktu gliserolisis. 


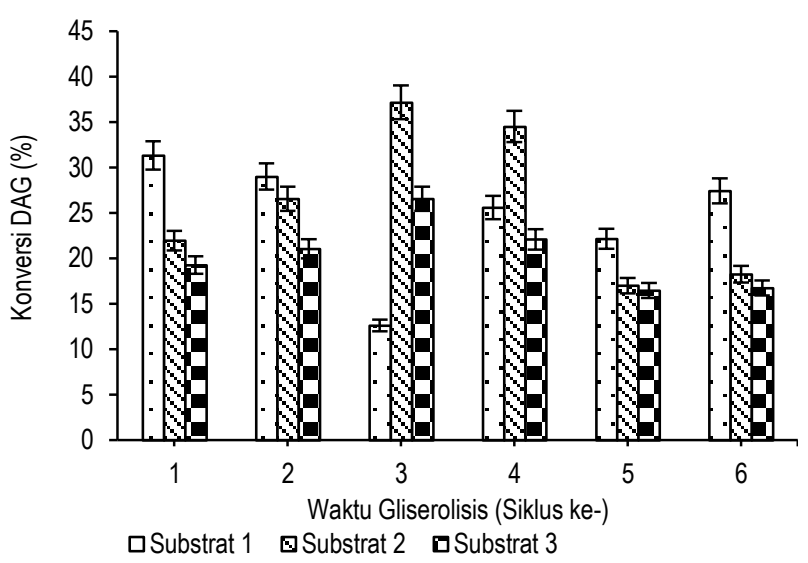

Gambar 8. Konversi produk DAG hasil gliserolisis dengan 3 kali pergantian substrat CPO dibandingkan komposisi awalnya

Pada proses optimasi waktu gliserolisis (Gambar 3), adanya penurunan fraksi massa DAG setelah jam ke-9, disebabkan karena kondisi tersebut sudah mencapai kondisi optimumnya, sehingga tidak dapat lagi meningkatkan fraksi massa produk yang berdampak pada nilai konversinya hanya mencapai $29 \%$ (Gambar 5). Akan tetapi setelah diberi perlakuan penggantian substrat yang baru, diduga hal inilah yang menjadi suplai (donor) asil baru yang kembali tersedia untuk membentuk tambahan fraksi massa DAG baru, sehingga nilai konversinya menjadi lebih tinggi, yaitu mencapai $37 \%$.

Kelemahan proses gliserolisis kontinu yang dilakukan dalam penelitian ini, yaitu enzim lipase yang digunakan dalam proses gliserolisis masih dalam bentuk ekstrak kasar, sehingga konversi produk DAG yang dihasilkan belum maksimal. Untuk meningkatkan konversi DAG dalam proses gliserolisis kontinu, perlu dilakukan perlakuan terhadap lipase itu sendiri agar stabilitas dan aktivitas katalitiknya menjadi semakin besar dan berkorelasi dengan terbentuknya fraksi massa produk dan nilai konversi produk DAG yang lebih tinggi, salah satunya dapat dilakukan dengan tahapan pemurnian lipase, atau melakukan rekayasa genetik terhadap mikroba penghasil lipase untuk menghasilkan enzim dengan aktivitas dan stabilitas yang lebih baik.

\section{KESIMPULAN}

Proses gliserolisis enzimatis untuk produksi DAG yang dilakukan secara kontinu untuk tujuan otomatisasi telah berhasil dilakukan. Berdasarkan kondisi yang diteliti, hasil terbaik pada proses optimasi produksi DAG melalui gliserolisis kontinu dicapai pada laju alir substrat (CPO) $3 \mathrm{~mL} / \mathrm{menit}$; waktu gliserolisis siklus ke-18 (9 jam), waktu optimum gliserolisis kontinu tersebut mencapai dua kali lipat lebih cepat dari penelitian sebelumnya yang dilakukan dengan sistem batch serta; penentuan kinerja lipase menunjukkan bahwa lipase mampu mengkatalisis proses gliserolisis kontinu dengan baik ditandai dengan pembentukan fraksi massa produk DAG yang relatif stabil hingga 3 kali perlakuan penggantian substrat CPO selama 9 jam gliserolisis dan kondisi terbaik dicapai pada penggantian substrat ke-2 dan waktu gliserolisis siklus ke-3 dengan nilai konversi sebesar $37 \%$.

\section{DAFTAR PUSTAKA}

Anggirasti, Hariyadi P, Andarwulan N, Haryati T. 2008. Gliserolisis RBDPO (Refined Bleached Deodorized Palm Oil) dengan Lipase untuk Sintesis MDAG (Monodiasilgliserol). Dalam Prosiding Seminar PATPI, Palembang. 1062-1070.

Kaewthong W, Sirisansaneeyakul S, Prasertsan P, Kittikun AH. 2005. Continuous production of monoacylglycerols by glycerolysis of palm olein with immobilized lipase. Process Biochem 40: 1525-1530. DOI: 10.1016/j.procbio.2003.12. 002.

Kittikun AH, Kaewthong W, Cheirsilp B. 2008. Continuous production of monoacylglycerols from palm olein in packedbed reactor with immobilized lipase PS. Biochem Eng 40: 116-120. DOI: 10.1016/j.bej.2007.11.023.

Lumor SE, Akoh CC. 2008. Esterification and hydrolytic activities of Candida rugosa lipase isoform 1 (LIP1) immobilized on celite 545, duolite A7, and sephadex G-25. J Agr Food Chem 56: 10396-10398. DOI: 10.1021/jf802136d.

Matsuo N. 2004. Nutritional characteristics and health benefits of diacylglycerol in foods. Food Sci Technol Res 10: 103110. DOI: $10.3136 /$ fstr.10.103.

Morita O, Soni MG. 2009. Safety assessment of diacylglycerol oil as an edible oil: a review of the published literature. Food Chem Toxicol 47: 9-21. DOI: 10.1016/j.fct.2008.09.044.

Noureddini H, Harkey DW, Gutsman MR. 2004. A continuous process for the glycerolysis of soybean oil. J Am Oil Chem Soc 81: 203-207. DOI: 10.1007/s11746-004-0882-y.

Nuraida L, Anggraini D, Mintarti IS, Haryati T. 2008. Kajian Aktivitas Antimikroba Monoasilgliserol dan Monodiasilgliserol dari Minyak Kelapa dan Minyak Inti Sawit. Dalam Prosiding Seminar Tahunan MAKSI 2008. Bogor, Masyarakat Perkelapa-Sawitan Indonesia (MAKSI) \& SEAFAST Center, IPB. p 204-214.

Sasi P, Mehrotra RR, Debnath M. 2006. Esterification reactions catalyzed by surfactant-coated Rhizopus arrhizus lipase. Indian J Biotechnol 5: 364-367.

Suharyanto, Tri-Panji, Abdullah MI, Syamsu K. 2006. Biokonversi CPO dengan desaturase amobil sistem kontinu pada skala semipilot untuk produksi minyak mengandung GLA. Menara Perkebunan 74: 96-105.

Suharyanto, Tri-Panji, Perwitasari U. 2011. Optimasi produksi diasilgliserol dari crude palm oil menggunakan lipase spesifik 1.3-gliserida dari Rhizopus oryzae TP-2. Menara Perkebunan 79: 23-29. 
Takase H. 2007. Metabolism of diacylglycerol in humans. Asia Pac J Clin Nutr 16: 398-403.

Tri-Panji, Suharyanto, Arini N. 2008. Lipase spesifik 1,3gliserida dari fungi lokal untuk biokonversi CPO menjadi diasilgliserol. Menara Perkebunan 76: 11-22.

Turner C, King JW, Mckeon T. 2004. Selected uses of enzymes with critical fluids in analytical chemistry. J AOAC Int 87: 797-810.
Valerio A, Rovani S, Treichel H, de Oliveira D, Oliveira JV. 2010. Optimization of mono and diacylglycerols production from enzymatic glycerolysis in solvent-free systems. Bioprocess Biosys Eng 33: 805-12. DOI: 10.1007/s00449009-0402-1.

Yuan Q, Ramprasath VR, Harding SV, Rideout TC, Chan YM, Jones JH. 2010. Diacylglycerol oil reduces body fat but does not alter energy or lipid metabolism in overwight, hypertriglyceridemic women. J Nutr 140: 1122-1126. DOI: 10.3945/jn.110.121665. 